Melina M. Nikolic ${ }^{*}$

Alfa BK univerzitet

Fakultet za strane jezike

Maja M. Ćuk

Alfa BK univerzitet

Fakultet za strane jezike https://doi.org/10.18485/analiff.2020.32.2.8

821.111(71).09 Етвуд М.

Originalni naučni rad

Primljen: 22.07.2020

Prihvaćen: 25.09.2020

\title{
AKTIVIZAM MARGARET ETVUD KROZ PRIZMU KRITIČKE ANALIZE DISKURSA
}

Kanadska književnica Margaret Etvud, osim po svom književnom stvaralaštvu, poznata je i po političkoj i društvenoj angažovanosti između ostalog po pitanju ljudskih prava, naročito prava žena, očuvanja životne sredine, kao i kanadskog kulturnog identiteta. Njeni satiričarski i moralizatorski stavovi jasno se oslikavaju kroz njena literarna dela, ali i kroz druge oblike komunikacije sa javnošću. U ovom radu ćemo pokušati da pojedine njene stavove od šireg društvenog značaja sagledamo iz perspektive kritičke analize diskursa koja posmatra diskurs u okviru društvenog i kulturnog konteksta i sagledava ga iz kritičke perspektive. Teorijsko utemeljenje ove lingvističke discipline zasniva se na proučavanju jezika i njegove upotrebe u socio-kulturnom kontekstu u funkciji uspostavljanja, održavanja i narušavanja odnosa moći među učesnicima u diskursu. Za analizu je korišćen metodološki okvir kritičke analize diskursa prema trodimenzionalnom modelu analize korpusa kao (1) teksta, (2) diskurzivne prakse i (3) društvene prakse, sa ciljem da se utvrdi kakav lingvistički obrazac Margaret Etvud koristi da bi izrazila svoje stavove u medijskom intervjuu. Istraživanje je pokazalo da njen lingvistički obrazac sadrži širok dijapazon jezičkih sredstava i diskurzivnih strategija kojima autorka bilo eksplicitno bilo implicitno izražava svoj aktivizam i daje svoj doprinos razotkrivanju i rešavanju ovih problema.

Ključne reči: Margaret Etvud, medijski intervju, kritička analiza diskursa, analiza konverzacije.

\section{Aktivizam Margaret Etvud}

Politički kontekst, tj. nastojanje da se skrene pažnja na osetljiva društvena pitanja ima ključnu ulogu u književnom stvaralaštvu Margaret Etvud, ali i u njenom angažovanju u drugim sferama. Zahvaljujući talentu

*_melina.nikolic@alfa.edu.rs, nikolic.melina@gmail.com 
za pisanje koji je negovala od detinjstva, ali i „svojoj istrajnosti i hrabrosti da tematizuje kontroverzna pitanja iz svog okruženja“ (Ćuk, 2014: 7), ova značajna savremena kanadska književnica ima upečatljiv uticaj kako u naučnim krugovima, tako i u popularnoj kulturi i širem društvenom kontekstu. Po rečima Natali Kuk, istaknutog proučavaoca stvaralaštva Margaret Etvud:

Odgajana u podsticajnoj porodici ambicioznih ljudi, naučena da poštuje pojedinca, upoznata sa ciljevima vrednim njenog vremena i energije (briga o svetu prirode, podržavanje kanadske kulture, promovisanje ženskih prava), Etvudova je oplemenila ciljeve svoje književne posvećenosti: da drži ogledalo ispred svog društva i svog vremena, i dok to radi, da igra ulogu u njihovom preoblikovanju. (Cooke, 1998: 327).

Etvudova u svojim delima često razmatra stav patrijarhalne kulture prema ženi, zbog čega se dovodi u vezu sa feminizmom, iako sama opovrgava direktno dovođenje u vezu sa ovom orijentacijom. Zapravo, ne samo pomenuta problematika, već „bilo koja diskutabilna i stereotipna shvatanja ukorenjena kako u tradicionalnim, tako i u aktuelnim ,,mitologijama,“ od lokalnih političkih prilika u Kanadi do odnosa prema prirodi na globalnom nivou, predmet su preispitivanja i kritike ove književnice“(Ćuk, 2014: 8). Tako da možemo reći da je njen aktivizam usmeren u tri pravca: zalaganje za prava marginalizovanih pojedinaca (posebno žena), borba za očuvanje životne sredine i nastojanje da se oformi i očuva specifičan kanadski kulturni identitet.

Osim kroz književnost, Margaret Etvud „borbe“ iz pomenutih aspekata vodi kroz sopstvene naloge na Tviteru i Instagramu, gde objavljuje knjige koje joj se sviđaju, ali i linkove od kampanja i organizovanih događaja. Piše članke i stavlja svoj potpis na otvorena pisma iz razloga koje podržava: ekologija Grete Thunberg, sloboda govora, LGBTQ+ prava, ženska prava, i slično. U ovom istraživanju pokušaćemo da identifikujemo i objasnimo koja lingvistička sredstva i strategije diskursa koristi u jednom od najuticajnijih medijskih formi, televizijskom i novinskom intervjuu. Pod novinskim intervjuom podrazumevamo kako štampana tako i internet izdanja novina i časopisa.

\section{Kritički pristup medijskom diskursu}

Kritička analiza diskursa (u daljem tekstu CDA prema Critical dicourse analysis), kao teroija i metod, polazi od prevashodno etičkog pro- 
AKTIVIZAM MARGARET ETVUD KROZ PRIZMU KRITIČKE ANALIZE ...

blema, a to je nepravedna raspodela moći u društvu(Graham, 2018). Sama disciplina je nastala kao kritika društvenog poretka i društvenih konvencija i fokusira se na transformisanje svesti sa ciljem da se emancipuju osobe i grupe koje su na bilo koji način potlačene u svetu koji karakteriše neravnopravna raspodela moći. Način na koji se to može postići je angažovanje predstavnika CDA u razotkrivanju opresivnih jezičkih praksi, naročito ideoloških, jer jepolazište ove discipline da je jezik sredstvo kojim se raspodela moći održava (Fairclough 1992, 2001, 2017, van Dijk 2001, 2008,2015, Wodak 2001, 2015).

Pošto se svemu što je čovek stvorio ili na šta utiče može pristupiti kritički (Herzog, 2016: 12), CDA polazi od kritičke analize jezika sa ciljem da se skrivena značenja u diskursu razotkriju, opišu i protumače i na taj način identifikuju društveni problemi. Međutim, ovde se zadatak CDA ne završava. Postoje struje u okviru ove discipline, i sve ih je više, koje smatraju da se CDA mora aktivno uključiti i u rešavanje otkrivenih problema.Tako van Dijk smatra da je CDA zapravo ,analiza diskursa sa stavom" (2001: 96) i naglašava neophodnost da analitičari zauzmu aktivni, eksplicitan stav prema predmetu svog istraživanja i na taj način pokušaju da razotkriju nejednakosti u društvu i suprotstave im se (2015: 466), dok Rogers smatra da CDA treba da ,eksplicitno iznosi društvene probleme $\mathrm{i}$ pokušava da ih reši“" (2004: 4).

Ako je jezik sredstvo manipulacije ljudskom svešću, logično je de će se postupak manipulisanja sprovoditi na mestima i u vreme kada se može uticati na veliki broj ljudi istovremeno. U savremenom svetu najpogodnije mesto za takvu akciju su mediji. Srećom, iako mediji prevashodno služe za propagandu vladajućih struktura, tj. centara moći, ipak u tim istim medijima možemo povremeno čuti i druge glasove - glasove koji pokušavaju da prikažu svet onakvim kakav zapravo jeste, a ne kakvim nam ga predstavljaju oni koji imaju moć. Ti glasovi pokušavaju da razotkriju istine koje se kriju, da ih kroz svoj angažman identifikuju i objasne, da pomognu svima da ih postanu svesni, kao i da podstaknu ljude na akciju.

\section{Korpus i metodologija}

U ovom istraživanju analizirana su jezička sredstva i diskurzivne strategije koje Margaret Etvud koristi u svom društveno-političkom angažmanu kroz javni diskurs. Za analizu su korišćeni medijski intervjui (televizijksi i novinski) koji je dala tokom poslednje četiri godine. Svi intervjui 
se prvenstveno fokusiraju na njeno književno stvaralaštvo, međutim teme razgovora neizostavno uključuju i sadržaje koji čine okosnicu njenog društvenog angažmama.

Iz šest intervjua koja je dala za BBC Hardtalk 2016 (1), Entertainment Weekly 2017 (2), O,the Oprah Magazine 2019 (3), the Guardian 2019 (4) i 2020 (5) i Rolling Stone 2020 (6), odabrani su reprezentativni primeri za tri glavne teme o kojima Margaret Etvud aktivno govori: borba za ljudska prava, naročito prava žena, borba za očuvanje životne sredine i očuvanje kanadskog kulturnog identiteta.

Metodologija istraživanja se oslanja na trodimenzionalni model koji je osmislio i razvio Norman Fairclough (1992, 2001). Prema njegovom modelu, kritička analiza diskursa podrazumeva tri dimenzije ili faze: (1) deskripciju od koje se polazi u istraživanju; ona podrazumeva analizu formalnih odlika teksta, zatim (2) interpretaciju koja sledi i predstavlja analizu odnosa između teksta i interakcije i (3) objašnjenje koje čini završnu fazu analize i bavi se odnosom između interakcije i društvenog konteksta, tj. diskurzivne prakse i društvene prakse. Ovakav način analize predstavlja pokušaj da se ustanovi sistematski metod za proučavanje odnosa između teksta i njegovog društvenog konteksta. Ove faze se ne mogu uvek jasno razdvojiti, jer se često jezička sredstva u datom kontekstu koriste u okviru većih segmenata koji predstavljaju diskurzivne strategije i dobijaju svoje značenje samo u okviru celokupne interakcije.

Intervjui 1 i 6 su vođeni uživo, pa je ovde primenjena i konverzaciona analiza koja se uglavnom odnosi na metalingvističke elemente kao što su prekidanje sagovornika i ćutanje ${ }^{1}$ i njihove funkcije u diskursu.

Analizom jezičkih sredstava i diskurzivnih strategijakoje Margaret Etvud koristi u svom diskursu pokušćemo da utvrdimo jezički obrazac koji koristi da bi izrazila svoje stavove.

Pošto polazimo od analize teksta, $t \mathrm{j}$. jezičkih elemenata, primeri nisu prevođeni jer se tokom prevoda mogu izgubiti pojedine karakteristike specifične za izvorni jezik.

\section{Analiza aktivističkog diskursa Margaret Etvud}

U istraživanju smo pošli od pretpostavke da Margaret Etvud u svom aktivističkom diskursu koristi određena jezička sredstva i diskurzivne strategije kojima implicitno ili eksplicitno izražava svoje stavove. Na prime-

1 Za detaljniji uvid u metodologiju konverzacione analize na televizijskom intervjuu videti Nikolić 2015, 2017 i 2018. 
AKTIVIZAM MARGARET ETVUD KROZ PRIZMU KRITIČKE ANALIZE ...

rima uzetim iz pomenutih intervjua pokušaćemo da ta sredstva i strategije identifikujemo i interpretiramo i da pokažemo njihove funkcije. Prikazaćemo ih kroz pojedinačne teme kroz koje se ogleda njen aktivizam, koji se se prevashdno odnosi na borbu za ljudska prava, naročito prava žena, očuvanje životne sredine i očuvanje kanadskog identiteta.

Analizu počinjemo rečenicom iz intervjua od 12. septembra 2020. godine koju su obeležili pandemija, dalje ugrožavanje ljudskih prava i sve ozbiljnije klimatske promene. Ovo je primer u kojem Etvudova ekslpicitno izražava svoje stavove:

Primer $1(5)^{2}$

MA: If you have a situation where you feel your rights are being removed, it's important to talk about it clearly.[...] If you're going to speak truth to power, make sure it's the truth. That's a good maxim.

Upotrebom takozvanog nultog kondicionala naglašava se da svaki uzrok nužno implicira posledicu. Margaret Etvud ovaj tip kondicionala koristi uz imperativ kojim insistira da svaki put kada imamo problem, u ovom slučaju ugrožavanje ljudskih prava, treba da jasno i pre svega istinito govorimo o problemima. Ovog principa se ona neprikosnoveno drži i eksplicitno govori o svemu za šta se zalaže. Takođe šalje i jasnu poruku svima da kad dođu u priliku da ,imaju moć“, pa makar to bila samo mogućnost da negde javno mogu nešto da kažu, to i treba da kažu. Upotrebom inkluzivne zamenice you koja se odnosi na sve ljude, svojim primerom pokušava da utiče na druge.

Međutim, njen se aktivizam može videti i implicitno kroz gotovo svaku temu o kojoj govori. Jer, ne može se baš sve reći direktno, naročito ne u javnom diskursu. Naredni primeri se odnose na ljudska prava.

\section{Ljudska prava}

Primer 2 (1)

$\mathrm{IR}^{3}$ : There is one other thing I want to talk to you about, which is your very passionate challenge to the Canadian government

2 Broj u zagradi iza svakog primera označava iz kog je intervjua primet preuzet. Spisak intervjua dat je u Korpusu na kraju rada.

3 U svim primerima je voditelj ili reporter označen skraćenicom IR (prema engleskom interviewer). MA označava Margaret Etvud (Margaret Atwood). 
over this legislation, C51, which you say is a fundamental threat to freedom of speech $\left[{ }^{4}\right.$ in Canada...

MA: [Well, it is. It's a...

IR: Others would [disagree.

MA: [It is a throwback to the Inquisition. So, when last did we have a situation where people who you don't even know who they are, can testify against you and you have got no right to reply. You know how weird is that?!

Hiljade ljudi protestovalo je u Kanadi tokom 2015. i 2017. zbog predloga novog zakona prema kojem bi porasla moć policije i tajnih službi u nadgledanju građana. Mada je konzervativna vlada tvrdila je da će novi zakon povećati bezbednost Kanađana, demonstranti su potpisali peticiju protiv uvođenja zakona, poznatog kao C-51, zbog bojazni da on krši civilnu slobodu i pravo na privatnost, tj. da bi usvajanje novog zakona omogućilo povećanje razmene informacija i dovodilo do pritvaranja ljudi samo zbog,,puke sumnje“.

Etvudova koristi dve diskurzivne strategije za kritiku tog zakona: poređenje sa opštepoznatim primerima loše prakse i retoričko pitanje uz dozu sarkazma. Pomenuti zakon poredi sa periodom inkvizicije koji se smatra jednim od najmračnijih perioda ljudske istorijepo pitanju osnovnih ljudskih prava, i time izražava svoju bojazan u pogledu posledica do kojih usvajanje pomenutog zakona može da dovede i do koje mere on predstavlja ugrožavanje slobode govora. Ceo utisak pojačava postavljanjem retoričkog pitanja koje ne zahteva odgovor, ali nas tera da o njemu razmišljamo. Cilj postavljanja retoričkog pitnja iz perspektive CDA tokom medijskog intervjua je zapravo poruka slušaocima, dakle široj javnosti, da zastanu i pokušaju da razmisle o odgovoru koji je zapravo poznat svima. Konačno, upotrebom prideva weird (čudno) sarkastično umanjuje značaj cele situacije, što je, paradoksalno, zapravo čini još ozbiljnijom.

Osim toga, ovde primećujemo i diskurzivnu strategiju prekidanja sagovornika i preuzimanja reči karakteristčnu za konfrontacioni intervju. Ona predstavlja način da se preuzme kontrola u diskursu, što Margaret Etvud uspešno sprovodi.

4 Otvorene uglaste zagrade označavaju prekidanje sagovornika, što je čest slučaj u konfrontacionom intervjuu kakav je i ovaj odakle je uzet primer. 
AKTIVIZAM MARGARET ETVUD KROZ PRIZMU KRITIČKE ANALIZE ...

Na pitanje zašto je baš sada (2019) izašao nastavak čuvenog romana Sluškinjina priča, ona odgovara (ovaj odgovor je uzet i za naslov intervjua):

Primer 3 (4)

MA: For a long time we were going away from Gilead and then we turned around and started going back towards Gilead, so it did seem pertinent.

Gilead, fiktivna zemlja iz distopijskog romana Sluškinjina priča, postala je simbol ugnjetavanja žena, ugroženosti svih ljudskih prava, ali i ekološke katastrofe. U ovom primeru Margaret Etvud prvenstveno misli na ljudska prava uopšte i koristi antonimijušto implicira da ona smatra da se vrtimo u začaranom krugu: samo što smo pomislili ili se ponadali da je nešto postalo dobro, da se udaljavamo od totalitarizma, da se udaljavamo od nečeg lošeg, krećemo unazad, ka tom istom lošem ${ }^{5}$. Efekat antonimije je utoliko jači što upotrebljava isti glagol go(ići) sa različitim prilozima za pravac. Ovde je jasno implicitno nagoveštavanje da se ljudima polako oduzimaju osnovna građanska prava.

\section{Prava žena}

U ovom podužem primeru vidimo brojne jezičke elemente i strategije koje Etvudova koristi kada govori o pravima žena.

Primer 4 (2)

IR:We live in a patriarchy, we live in a particular power structure. Do you think it's possible for all women to be harmonious with each other? I'm interested in whether it's harder because of the shape of the power structure and our place within it.

5 Treba napomenuti da je ovaj intervju vođen u vreme kada je Boris Džonson najavio mogućnost raspuštanja parlamenta zbog Bregzita (septembar 2019). Kao i nakon predsedničkih izbora u SAD 2016. kada je Donald Tramp postao predsednik, i u ovom trenutku su ljudi masovno delili citat iz Sluškinjine priče: „That was when they suspended the Constitution. They said it would be temporary. There wasn't even any rioting in the streets. People stayed at home at night, watching television." (The Handmaid's Tale, 268) (Tada su suspendovali Ustav. Rekli su da je to privremena mera. Na ulicama nije bilo čak ni nereda. Ljudi su noću ostajali kod kuće, gledali televiziju. Sluškinjina priča,190)

Moramo takođe podsetiti, mada to nije tema ovog rada, da je Etvudova oštar kritičar američkog imperijalizma, naročito Donalda Trampa čiju vlast poredi sa svojim imaginarnim totalitarističkim društvom iz pomenutog romana, i vezuje je za ugnjetavanje $\mathrm{i}$ ugrožavnaje osnovnih ljudskih prava, mada to ne iznosi eksplicitno. 
MA: Of course; there are hard things. But we're human beings! It's possible for men to be harmonious with one another even though they're often very competitive. But women too are human beings, that's my foundational belief — so they're not exempt from the emotions that human beings have. Love, hate, jealousy, competitiveness, cooperation, loyalty, betrayal - the whole package.And we don't live in just "a" patriarchy, we live in a number of different kinds of patriarchies. You can pinpoint the moment in which women started to be treated markedly worse than men (advent of wheat and agriculture). Let me put it to you this way: Amongst the Inuit things are somewhat more equal because each half contributes to not just the welfare but the existence of the other. So men do the hunting by and large, but in order to do the hunting they have to wear waterproof clothing that is expertly made by women. If you make faulty clothing the man will get wet and then he will freeze to death. And your kayak is viewed as a piece of clothing that's fitted to you so if you roll your kayak the water will not get in and you'll right yourself. Making the clothing is a very laborious process, and it's an expert skill and highly valued; so in societies in which women do something that is highly valued, of course their place is going to be more equal. We know this through micro financing [...] Microfinancing businesses will not lend money to men, they only lend to women, because they say the women have an interest in helping their families whereas the men might spend it on just showing off. So all of that is to be taken into consideration; but none of it means that women are exempt from bad individual behavior towards one another.

IR: Definitely not! Misogyny has no gender.

MA: Yes. And it has nothing to do with whether women should have voting rights. If voting rights were determined on all men behaving well, they wouldn't have any. Rights as citizens are quite apart from individual behavior.

Borba za prava žena je jedna od glavnih tema kako u književnim delima tako i u drugim vidovima njenog obraćanja javnosti. Naročito je zanimljiv njen diskurs o ženama i muškarcima. Na provokativno pitanje intervjuerke da li je,u specifičnoj strukturi moći u kojoj živimo, moguće da 
AKTIVIZAM MARGARET ETVUD KROZ PRIZMU KRITIČKE ANALIZE ...

sve žene žive $u$ harmoniji jedna sa drugom, odgovor daje u vidu poređenja uz navođenje brojnih primera ${ }^{6}$.

Čitav diskurs se svodi na poređenje žena sa mukarcima, ali ona nikad niti tvrdi niti implicira da su žene bolje od muškaraca, već insistira na tome da su iste, da su isto kao i muškarci ljudska bića, da isto kao i oni imaju emocije kao što su ljubav, mržnja, ljubomora, takmičarski duh, lojalnost, izdaja, sve što i muškarci. Žene su dobre koliko i muškarci, žene su i loše koliko i muškarci. Ona jasno kaže da žene takođe umeju da loše tretiraju jedne druge. U skladu sa time, kada je reč o pravu glasa, ona apsolutno smatra da i žene treba da ga imaju, što zapravo znači da treba da u svemu budu potpuno ravnopravne sa muškarcima.

Svoju borbu za ženska prava mudro vodi kritikujući muškarce, a ne hvaleći žene: „Ako bi se pravo glasa dodeljivalo svim muškarcima koji se lepo ponašaju, niko ga ne bi dobio“; „Mikrokredite ne dobijaju muškarci, već samo žene, jer je ženama u interesu da pomažu svojim porodicama, dok bi ih muškarci možda potrošili da bi se pravili važni.“

\section{Feminizam i prava žena}

Primer 5 (2)

IR: Are you bored of the "Are you a feminist" question? You must have been asked that a lot whilst talking about the new TV show.

MA: I'm not bored with it, but we have to realize it's become one of those general terms that can mean a whole bunch of different things, so I usually say, "Tell me what you mean by that word and then we can talk." If people can't tell me what they mean, then they don't really have an idea in their heads of what they're talking about. So do we mean equal legal rights? Do we mean women are better than men? Do we mean all men should be pushed off a cliff? What do we mean? Because that word has meant all of those different things. [...]It's like Christians. Do we mean the Pope? Do we mean Mormons? What are we talking about here? Because they're quite different.

Izbegavanje odgovorapredstavlja strategiju u diskursu kada želimo da $\mathrm{u}$ potpunostiili samo delimično izbegnemo odgovor na pitanje, ali i

6 Zbog dužine navodimo samo najreprezentativnije primere. 
kada želimo da u okviru odgovora uvedemo novu temu. Margaret Etvud to često koristi i na taj način govori o temama koje su njoj bitne čak i kada nije upitana o njima.

U ovom primeru, na pitanje da li je feministkinja ona odgovara pitanjem, tačnije nizom pitanja, i vešto koristi strategiju izbegavanja direktnog odgovora. Iako feminizam leži u osnovi gotovo svega što piše, ona odbija da se izjasni kao feministkinja baš iz ovog razloga, jer se ne slaže sa svakim značenjem te reči, pa samim tim i celog pokreta. Zato ovde eksplicitno objašnjava: „kažite mi šta podrazumevate pod tim pojmom i tada možemo da razgovaramo“.

Nakon što je prvo upotrebila strategiju izbegavanja odgovora, dodatno naglašava ovaj semantički problem upotrebom analogije. Kompleksno značenje reči feminizam poredi sa takođe složenim značenjem reči hrišćani:,Da li mislimo na Papu? Da li mislimo na Mormone? O čemu ovde govorimo?"

\section{Očuvanje životne sredine}

Primer 6 (3)

IR:Climate change is at the heart of both The Handmaid's Tale and The Testaments...

MA:We're now calling it climate crisis. It's no longer just a change. It's gone beyond that. [...]People have known about and talked about a coming climate crisis for a really long time. It's just that the general population either wasn't aware, wasn't interested, wasn't listening, or did that thing that we all do, which is, "Well, it won't happen tomorrow." We all do that. We are lowhanging fruit pickers, and one-day-at-a-timers, and if it's not threatening you right now, you often just don't pay attention to it because you're paying attention to other things that are more of a nuisance at that moment.

Izbor vokabulara ovde ukazuje na potrebu podizanja svesti o ozbiljnosti problema o kojem je reč. Voditeljka započinje priču o klimatskim promenama, ali je Etvudova ispravlja i naglašava da je promena prerasla u krizu.Zatim koristi gradaciju kojom ističe potrebu da se sa spoznaje pređe na delanje. Ljudi isprva nisu svesni, zatim možda nisu zainteresovani ili ne slušaju o problemu, i konačno čak i kada postanu svesni ništa ne čine. Ona implicira da treba da se počne sa akcijom, da svako treba da da svoj dopri- 
AKTIVIZAM MARGARET ETVUD KROZ PRIZMU KRITIČKE ANALIZE ...

nos. Upotrebom živopisnih složenicaljudima upućuje ozbiljnu kritiku da idu linijom manjeg otpora (low-hanging fruit pickers)i da žive „od danas do sutra“" (one-day-at-a-timers), međutim, pošto upotrebljava zamenicu we (tzv. inkluzivno $m i$ koje uključuje kako govornika tako i slušaoce), sebe stavlja u isti položaj i preuzima deo krivice na sebe, pa samim tim uzima sebi za pravo da svima uputi oštru kritiku.

Na pitanje o klimatskim promenama i čovekovom uticaju na svoju životnu sredinu u sledećem primeru ona odgovara jakom porukom:

Primer 7 (6)

Let's hope that people start taking climate deterioration and planet deterioration seriously because if they don't,goodbye human race! And all of these other things that we've been talking about are simply irrelevant. So, it doesn't matter if you're a great artist, you know, if everybody's dead.

Videli smo u prethodnom primeru da su za Etvudovu klimatske promene prerasle u krizu, a ovde koristi još jaču reč koja implicira da je za propadanje životne sredine odgovoran čovek ${ }^{7}$, a predviđanja su pesimistična. Ona nam jasno stavlja do znanja da to vodi smrti čovečanstva.

Ako primere 6 i 7 analiziramo zajedno, možemo pratiti upotrebu kolokacija sa leksemom climate. U prvom slučaju reč je o kolokaciji neutralnog polariteta, jer promena ne mora sama po sebi biti ni dobra ni loša. U ostala dva slučaja polaritet prelazi u negativni sa imenicama crisis i deterioration, i već same kolokacije imaju negativnu konotaciju i naša sagovornica ih koristi kao upozorenje. ${ }^{8}$

\section{Kanadski identitet i ugrožavanje životne sredine}

Kako voditelj sledećeg intervjua zna da se njegova gošća bori za očuvanje životne sredine a istovremeno se zalaže i za kreiranje i očuvanje

$7 \quad$ Environmental degradation is the deterioration of the environment through depletion of resources such as air, water and soil; the destruction of ecosystems; habitat destruction; the extinction of wildlife; and pollution. https://en.wikipedia.org/wiki/ Environmental_degradation\#: :text=Environmental\%20degradation\%20is\%20the\%20 deterioration,extinction $\% 20$ of $\% 20$ wildlife $\% 3$ B $\% 20$ and $\% 20$ pollution.\&text=When $\% 20$ natural\%20habitats\%20are\%20destroyed,depleted $\% 2$ C\%20the\%20environment $\% 20$ is\%20degraded.

8 Detaljnije o kolokacijama iz perspektive CAD videti u Jevrić, Nikolić 2019. i Nikolić, Jevrić 2019. 
kanadskog identiteta, ovde primenjuje strategiju uvođenja dve teme koje su u kontrastu da bi isprovocirao intervjuisnu osobu se opredeli za jednu.

Primer 8 (1)

IR: Here you have a young Prime Minister, Mr Trudeau, who says, well, he has indeed signed up to the Paris Climate Change Agreement, he says he is going to cut Canadass emissions by $30 \%$, and yet at the very same time he is supporting the expansion of the Tar sands and clearly within decades you are going to be, if not the biggest but the second biggest oil producer in the world if current trends continue.

MA: Maybe, maybe not, I don't think he's supported the expansion of the Tar sands as such. I think he supported a pipeline.

IR: The two go together.

MA: Some would say that. There is $\operatorname{some}(. . .)^{9}$ debate possible.

Ovaj primer je zanimljiva kombinacija dve teme koje ovde analiziramo. I stiče se utisak da je Etvudova ovde prinuđena da odstupi. Naime, ovaj primer je uzet iz konfrontacionog diskursa televizijskog intervjua Hardtalk, koji se od klasičnog intervjua razlikuje po provokativnijim pitanjima (Nikolić, 2017). Voditelj uvodi dve teme za koje se Margaret Etvud zalaže, ali kad dođe do kanadskog premijera i ugrožavanja čovekove sredine, čak ni ne postavlja pitanje. Njegova gošća treba da se opredeli između podrške svojoj zemlji i zalaganja za zaštitu okoline.

U stilu svojstvenom konfrontacionom intervjuu, voditelj gradi pitanje navodeći prvo pozitivnu činjenicu (kanadski premijer je obećao da će smanjiti zagađenje do $30 \%$ ), a zatim odmah uvodi i negativnu (on se istovremeno zalaže za ekspanziju naftnog peska, što će u roku od nekoliko decenija Kanadu učiniti jednim od najvećih proizvođača nafte). Tako je Etvudova prinuđena da se posluži nizom ograda da ne bi morala da se eksplicitno izjasni po ovom pitanju. Voditelj je primorava da se odluči za jednu od dve stvari koje su očigledno suprotstavljene i nije moguće podržati obe: ili će ostati dosledna po pitanju davanja podrške svemu što čini kanadski identitet ili će nastaviti da se zalaže za očuvanje čovekove okoline. Ona koristi prvo modalni prilog maybe, a odmah zatim i najčešći gla-

9 Oznaka za pauzu u govoru, prema konvencijama konverzacione analize. 
AKTIVIZAM MARGARET ETVUD KROZ PRIZMU KRITIČKE ANALIZE ...

gol ograđivanja think. Nakon još jedne provokacije (The two go together.), upotrebljava i modalni glagolwould, kao i modalni pridev possible, što jasno ukazuje na njeno oklevanje i izbegavanje da direktno odgovori na postavljeno pitanje. Ove ograđivače koristimo kada želimo da izbegnemo da se jasno izjasnimo po nekom pitanju. Osim toga, njeno oklevanje se može videti i zbog pauze koju pravi u govoru u poslednjoj rečenici, koja ukazuje na nesigurnost $\mathrm{u}$ odabir reči.

Kao i u primeru 4 i ovde se služi strategijom delimičnog izbegavanja odgovora, osim što je tehnika različita (retorička pitanja nasuprot ograđivanju).

\section{Zaključak}

Aktivizam Margaret Etvud počinje u njenim književnim delima, ali se ona tu ne zaustavlja, već nastavlja da se i kroz druge oblike društvenog angažmana bori za dobrobit ljudi.Ona se javno zalaže za svoje ideje, aktivno se angažuje oko gorućih društvenih problema i nema problem da to javno kaže. U ovom radu se nismo bavili primarnim oblikom njenog delovanja, književnošću, već jezičkimobrascem kojim se služi u javnom medijskom diskusu kao sredstvom svoje kampanje. Cilj ovog istraživanja je bio da se utvrdi da li se njeni stavovi osim kroz stvaralaštvo mogu videti i kroz njen diskurs, kao i kojim se jezičkim sredstvima i strategijama u diskursu služi.

Vidimo da koristi svaku priliku da govori o temama koje smatra važnim, čak i ne čeka da joj pitanje bude postavljeno. Jedna od najuočljivijih strategija koju koristi je upravo uvođenje teme za koju se zalaže u dijalog čak i kada nije o tome upitana.

Svaka njena izjava ima težinu. Reči ne koristi olako, već veštinom vrsne književnice i u intervjuima koristi sve tajne svog zanata da na upečatljiv, ali ne previše očigledan i direktan način natera slušaoce/čitaoce da razmišljaju o temama o kojima govori. Pre svega njen lingvistički obrazac čini pažljiv odabir vokabulara, zatim upotreba raznovrsnih jezičkih sredstava i strategija kao što su poređenje, ilustracije, analogije, gradacije, antonimija, pa i delimično izbegavanje odgovora, samostalno uvođenje teme, preuzimanje reči i slično.

Diskurs koji koristi u medijima u potpunosti potvrđuje njene knjiženvne stavove, čak su usmeno i jasniji i eksplicitniji. Često neka njena izjava predstavlja eho stava iznesenog u nekom romanu, ali kada se izvuče iz 
konteksta i naglasi tokom intervjua dobija i dodatno značenje i značaj, jer tada može da se transponuje na svakodnevnu realnost i da se bolje poveže sa postojećim društvenim strukturama i odnosima moći. Samim tim njene reči dobijaju veću moć.

Konačno, kao potvrdu da se njene reči čuju i pravilno tumače, možemo napomenuti da se posledice ovakvog aktivizma mogu jasno uočiti kroz primere demonstracija širom sveta u simboličnim kostimima iz njenog najpoznatijeg dela Sluškinjina priča. Sasvim sigurno to nije posledica isključivo popularnosti njenog romana, već i njene neprekidne borbe za ostvarivanje prava žena širom sveta. Vidimo i poslednjih dana devojke i žene obučene u karakteristične crvene kostime, koji su postali simbol ženskog otpora i prkosa, tokom protesta u Poljskoj protiv usvajanja spornog zakona o gotovo potpunom ukidanju prava na abortus (https://www.insider.com/protestors-storm-churches-in-poland-over-new-abortion-restrictions-2020-10, https://wyborcza.pl/7,173236,26421150,a-handmaid-s-tale-of-the-constitutional-tribunal-women-s-rights.html?disableRedirects=true).

\section{KORPUS}

1) BBC - https://www.bbc.co.uk/programmes/p04bjb5x

2) Entertainment Weekly - https://ew.com/books/2017/07/14/emma-watson-interviews-margaret-atwood-handmaids-tale/

3) O, The Oprah Magazine - https://www.oprahmag.com/entertainment/books/ a28944955/margaret-atwood-the-testaments-interview/

4) The Guardian - https://www.theguardian.com/books/2019/sep/20/margaretatwood-moving-away-from-gilead-testaments

5) The Guardian - https://www.theguardian.com/lifeandstyle/2020/sep/12/margaret-atwood-if-youre-going-to-speak-truth-to-power-make-sure-its-thetruth

6) Rolling Stone - https://www.rollingstone.com/culture/culture-features/margaret-atwood-handmaids-tale-testaments-authoritarian-feminism-1065629/

\section{LITERATURA}

Atvud, M. (2006). Sluškinjina priča. Beograd: Laguna.

Atwood, M (2016). The Handmaid's Tale. London: Penguin. 
Cooke, N. (1998). Margaret Atwood: a Biography. Toronto: ECW Press.

Ćuk, M. (2014). Margaret Etvud i mit : Novi svet u boji drevnih predanja. Beograd : Fakultet za strane jezike.

Fairclough, N. (1992). Discourse and Social Change, Cambridge: Polity Press.

Fairclough, N. (2001). Language and Power. 2nd edition, London: PearsonEducation.

Fairclough, N. (2017). CDA as dialectical reasoning. In J. Flowerdew and J. E. Richardson (Eds.) The Routledge Handbook of CriticalDiscourse Studies Abingdon and New York: Routledge.

Graham, P. (2018). Ethics in critical discourse analysis, Critical Discourse Studies, https://doi.org/10.1080/17405904.2017.1421243

Herzog, B. (2016). Discourse Analysis as Social Critique. London: Palgrave Macmillan.

Jevrić, T. \& Nikolić, M. (2019). The Examination of Collocations with Nouns Which Denote Human Beings in Confrontational Discourse. Nauka bez granica II (4), 69-83.

Nikolić, M. (2015). Metalinguistic means for expressing power in discourse. $\mathrm{Y}$ : Mišić Ilić, Biljana (ur.), Lopičić, Vesna (ur.). Jezik, književnost, diskurs, Jezičkaistraživanja. Zbornik radova. Niš: Univerzitet u Nišu, Filozofski fakultet, str. 327-338.

Nikolić, M. (2017). Pokušaj definisanja konfrontacionog intervjua, Anali filološkog fakulteta, Vol. 29, No. 1. стр. 125-148.

Nikolić, M. (2018). Analiza konverzacije: Kritički pristup tekstu. Reči: časopis za jezik, književnost i kulturu. Vol. X, No. 1. Str. 30-48

Nikolić, M. i Jevrić, T. (2019). Teorijska razmatranja o kolokacijama sa imenicama koje označavaju ljudska bića iz perspektive kritičke analize diskursa. U: Lopičić, Vesna (ur.), Mišić Ilić, Biljana (ur.). Jezik, književnost, teorija: Jezička istraživanja, zbornik radova. (Biblioteka Naučni skupovi). Niš: Filozofski fakultet. Str. 299-312

Rogers, R. (2004). An Introduction to Critical Discourse Analysis in Education. In An Introduction to Critical Discourse Analysis in Education. R. Rogers, ed., 1-18. Mahwah, New Jersey: Lawrence Erlbaum.

van Dijk, T. (2001). Multidisciplinary CDA: a plea for diversity. In: R. Wodak and M. Meyer (eds.), Methods of Critical Discourse Analysis, London: SAGE Publications, 95-120.

van Dijk, T. A. (2008). Discourse nad Power. Hampshire, New York: Palgrave Macmillan.

van Dijk, T. A. (2015). Critical Discourse Analysis. In Handbook of Discourse Analysis, second edition, D. Tannen, H.E. Hamiltin, D. Schiffrin (eds), 46685. Maiden and Oxford: John Wiley \& Sons. 
Wodak, R. (2001). The discourse-historical approach. In R. Wodak \& M. Meyer(Eds.), Methods of Critical Discourse Analysis (63-94). London: Sage.

Wodak, R. (2015). Critical Discourse Analysis, Discourse-Historical Approach. In:The International Encyclopedia of Language and Social Interaction. Tracy, K.(General Editor), Ilie, C. and Sandel, T. (Associate Editors). JohnWiley \& Sons, Inc. 275-288.

\title{
Melina Nikolić \\ Maja Ćuk
}

\section{MARGARET ATWOOD'S ACTIVISM THROUGH THE PRISM OF CRITICAL DISCOURSE ANALYSIS}

\begin{abstract}
Summary
Besides her literary work, Canadian author Margaret Atwood is also known for her political and social engagement when it comes to matters of human rights, especially women's rights, preservation of the environment, as well as Canadian cultural identity, among others. Her satirical and moralizing attitudes are clearly represented in her literary works, and also in other forms of communication with the public. The aim of the paper was to look at certain Atwood's attitudes of greater social importance through the prism of Critical Discourse Analysis, which studies discourse in social and cultural context and views it from a critical perspective. The theoretical background of this linguistic discipline is based on the study of language and its use in the socio-cultural context with the purpose of establishing, maintaining and disrupting power relations between discourse participants. We used the methodological framework of Critical Discourse Analysis based on the three-dimensional model of studying the corpus as (1) text, (2) discursive practice and (3) social practice, with a view to determining which linguistic pattern Margaret Atwood uses to voice her opinions in media interviews. The study has shown that her linguistic pattern contains a wide array of linguistic devices and discursive strategies, among others comparison, gradation, analogy, antonymy, illustration, as well as evasion strategies, introducing the preferred topic and taking over control in discourse. By doing so, the author manages to express her activism and contributes to the uncovering and solving of these issues, either in an implicit or explicit way.
\end{abstract}

Keywords: Margaret Atwood, media interview, Critical Discourse Analysis, Conversation Analysis. 